\title{
DAYA DUKUNG LAHAN PERTANIAN TANAMAN PANGAN DI KABUPATEN MINAHASA SELATAN
}

\author{
Andre Giant Galentsi Masengi \\ Celcius Talumingan \\ Juliana R. Mandei
}

\begin{abstract}
This research aims to determine the carryng capacity of agricultural land food crops in Southern Districts Minahasa. This research from preparation of the final report of the study conducted in March to June 2015. Data is taken from secondary data obtained from the Central Statistical Agencies and the Department of Agriculture in Southern Minahasa. The data analysis used is the level of the carryng capacity of agricultural land. From the research, the level of the carrying capacity of agricultural land in the subdistrict of Modoinding lowest was in the amount of 0,076 and the highest in the sub-district of Maesaan that is equal to 1,113. Carrying value of the level of agricultural land in the Southern District Minahasa amounted to 0,414. This means that the Southern Minahasa District has not been able to perform self-suffieciency and has not been able to provide a decent life for its people, therefore the carrying capacity of agricultural land food crops in Southern Minahasa district needs to be improved especially through increased productivity and reduce the rate of population growth.
\end{abstract}

Keywords: the carrying capacity, Agricultural Land Food Crops, Southern Minahasa

\begin{abstract}
ABSTRAK
Penelitian ini bertujuan untuk mengetahui besarnya daya dukung lahan pertanian tanaman pangan di Kabupaten Minahasa Selatan. Penelitian ini mulai dari persiapan hingga penyusunan laporan akhir penelitian di-laksanakan pada bulan Maret sampai Juni 2015. Data yang di ambil adalah data sekunder yang bersumber dari Badan Pusat Statistik dan Dinas Pertanian di Minahasa Selatan. Analisis data yang dipakai adalah tingkat daya dukung lahan pertanian. Dari hasil penelitian tingkat daya dukung lahan pertanian terendah terdapat pada Kecamatan Modoinding yaitu sebesar 0,076 dan tertinggi pada Kecamatan Maesaan yaitu sebesar 1,113. Nilai tingkat daya dukung lahan pertanian di Kabupaten Minahasa Selatan adalah sebesar 0,414. Hal ini berarti bahwa Kabupaten Minahasa Selatan belum mampu untuk melakukan swasembada pangan dan belum mampu memberikan kehidupan yang layak bagi masyarakatnya. Oleh karena itu daya dukung lahan pertanian tanaman pangan di Minahasa Selatan perlu di tingkatkan. Terutama melalui peningkatan produktifitas dan menekan laju pertumbuhan penduduk.
\end{abstract}

Kata kunci: Daya Dukung, Lahan Pertanian Tanaman Pangan, Minahasa Selatan

\section{PENDAHULUAN}

\section{Latar Belakang}

Pembangunan, merupakan suatu kegiatan yang dilakukan dengan suatu tujuan akhir yang ber- sifat abstrak yaitu mensejahterakan kehidupan penduduk yang berada di wilayah tersebut. Manusia merupakan mahluk hidup yang memiliki kebutuhan paling komplek dari pada mahluk hidup lainnya di muka bumi ini. Salah satu kebutuhan pokok manu- 
sia yaitu pangan. Manusia membutuhkan pangan untuk dapat melangsung-kan kehidupan dan beraktivitas di muka bumi ini.

Indonesia yang merupakan negara agraris, dengan sebagian besar penduduknya bekerja di sektor pertanian tentunya menggantungkan hidupnya pada lahan pertanian. Lahan pertanian sebagai tempat beraktifitas bagi petani semakin mengalami penurunan. Hal ini diakibatkan oleh semakin besarnya tekanan penduduk terhadap lahan pertanian.

Jumlah penduduk yang terus meningkat dan aktifitas pembangunan yang dilakukan telah banyak menyita fungsi lahan pertanian untuk menghasilkan bahan makanan yang diganti dengan pemanfaatan lain, seperti pemukiman, perkantoran dan sebagainya. Akibatnya keadaan ini menyebabkan kemampuan lahan pertanian untuk memenuhi kebutuhan makanan bagi penduduk semakin berkurang. Menurut Soemarwoto dalam Moniaga (2011), walaupun di dalam masyarakat terdapat mekanisme untuk mengatur laju pertumbuhan penduduk namun pada kenyataanya di banyak tempat terdapat tanda kepadatan penduduk yang telah melampaui daya dukung.

Tanda tersebut dapat dilihat melalui pemanfaatan daerah-daerah yang seharusnya dilindungi dengan menggarap hutan perlandangan, penyerobotan hutan lindung serta pemukiman liar pada lahan akan digunakan untuk pertanian. hal ini akan menimbulkan kerusakan lingkungan. Jumlah penduduk faktor utama menentukan banyaknya permintaan bahan konsumsi yang disediakan, begitu juga banyaknya fasilitas umum yang dibangun disuatu wilayah. (Taringan, 2004).

Indonesia yang memiliki luas lahan pertanian yang tetap dengan pertumbuhan penduduknya yang besar akan menyebabkan ketersediaan lahan pertanian menjadi semakin kecil. Apabila hal ini dibiarkan, maka akan terjadi ketidakseimbangan penduduk yang bekerja sebagai petani pada suatu wilayah dengan luas lahan pertanian yang ada. Akibatnya, tekanan penduduk pada lahan pertanian akan semakin besar atau dengan kata lain wilayah tersebut tidak mampu memenuhi kebutuhan pangan penduduknya. (Riyadi dan Bratakusumah, 2004).

Keadaan seperti sangat bertentangan, karena pertanian penduduk membawa konsekuensi pe- ningkatan kebutuhan akan bahan makanan dan ketersediaan bahan pangan merupakan hal penting dalam kehidupan. Pangan diperlukan sebagai sumber energi dan untuk mengatur metabolisme tubuh.

Makin besar presentase lahan yang dipakai untuk pertanian makin besar daya dukungnya. Untuk menganalisis daya dukung dalam penelitian ini digunakan analisis tentang tekanan penduduk.

Apabila terjadi kenaikan tekanan penduduk akan mendorong untuk memperluas lahan pertaniannya yang pada gilirannya usaha pertanian akan dipaksakan menggunakan lahan yang relatif kurang subur.

Alih fungsi lahan pertanian menjadi non pertanian sebenarnya bukan masalah baru, peningkatan jumlah penduduk menuntut pembangunan infrastruktur baik berupa jalan, bangunan, industri, dan pemukiman, hal ini tentu saja harus didukung dengan ketersediaan lahan.

Kabupaten Minahasa Selatan mengalami kenaikan jumlah penduduk paling tinggi terjadi pada Tahun 2012 ke 2013 sebesar 7,5\%. Seiring dengan meningkatnya jumlah penduduk luas lahan pertanian di Kabupaten Minahasa Selatan secara umum mengalami penurunan pada Tahun 2008 sebesar 44,9 \% dari Tahun sebelumnya 219.426 Ha menjadi 120.774. Kabupaten Minahasa Selatan mengalami pertumbuhan penduduk yang diikuti luas lahan pertanian menurun (Lagarense, 2015).

Penggunaan lahan menjadi kawasan permukiman, industri dan kawasan terbangun lainnya yang di ikuti pertumbuhan penduduk akan mempersempit lahan pertanian dan menyebabkan daya dukung tanaman pangan semaking berkurang. Setiap pertambahan jumlah penduduk pasti disertai dengan tuntutan pertambahan kebutuhan dasar (pangan, sandang, dan perumahan).

Kebutuhan pangan dan sandang berasal dari produksi pertanian, sedangkan kebutuhan bahan perumahan sebagian besar berasal dari sumber daya alam. agar produksi pangan dan sandang meningkat, maka produktivitas pertanian harus terus ditingkatkan , baik secara intensifikasi maupun ekstensifikasi (Salikin, 2003)

Kabupaten Minahasa Selatan merupakan salah satu Kabupaten yang ada di Provinsi Sulawesi Utara dengan luas wilayah $1.484,72 \mathrm{~km}^{2}$. Kabupa- 
ten Minahasa Selatan Memiliki 17 Kecamatan dengan jumlah Desa 177.

Meskipun Kabupaten Minahasa Selatan bukan merupakan sentra produksi tanaman pangan namun Kabupaten Minahasa Selatan memiliki berbagai jenis tanaman pangan. Pola penyebaran tanaman pangan di Kabupaten Minahasa Selatan tidak merata dan tidak terpusat pada satu daerah saja melainkan menyebar ke beberapa daerah. Pada Penelitian ini ingin melihat seberapa besar daya dukung lahan pertanian tanaman pangan di Kabupaten Minahasa Selatan.

\section{Daya Dukung Lahan}

Daya dukung Carring capacity lahan diartikan sebagai kemampuan lahan untuk mendukung perikehidupan manusia dan makhluk hidup lain. (Baja, 2012).

Menurut Lenzen dalam Idewa (2015), Kebutuhan hidup manusia dari lingkungan dapat dinyatakan dalam luas area yang dibutuhkan untuk mendukung kehidupan manusia. Carrying capacity atau daya dukung lingkungan mengandung pengertian kemampuan suatu tempat dalam menunjang kehidupan mahluk hidup secara optimum dalam periode waktu yang panjang. Daya dukung lingkungan dapat pula diartikan kemampuan lingkungan memberikan kehidupan organisme secara sejahtera dan lestari bagi penduduk yang mendiami suatu kawasan, yang dapat dijabarkan sebagai berikut.

1. Jumlah organisme atau spesies khusus secara maksimum dan seimbang yang dapat didukung oleh suatu lingkungan.

2. Jumlah makhluk hidup yang dapat bertahan pada suatu lingkungan dalam periode jangka panjang tampa membahayakan lingkungan tersebut.

3. Jumlah penduduk maksimum yang dapat didukung oleh suatu lingkungan tanpa merusak lingkungan tersebut.

4. Jumlah populasi maksimum dari organisme khusus yang dapat didukung oleh suatu lingkungan tanpa merusak lingkungan tersebut.

5. Rata-rata kepadatan suatu populasi atau ukuran populasi dari suatu kelompok manusia dibawah angka yang diperkirakan akan meningkat, dan diatas angka yang diperkirakan untuk menurun disebabkan oleh kekurangan sumber daya.
6. Kapasitas pembawa akan berbeda untuk tiap kelompok manusia dalam sebuah lingkungan tempat tinggal, disebabkan oleh jenis makanan, tempat tinggal, dan kondisi sosial dari masingmasing lingkungan tempat tinggal tersebut.

7. Daya dukung lingkungan adalah kemampuan lingkungan untuk mendukung perikehidupan manusia dan makhluk hidup lainnya, (Otto Soemarwoto dalam Arie, 2005).

Ada beberapa tingkat daya dukung, yaitu :

a. Daya dukung maksimum, menunjukan jumlah hewan yang dapat didukung persatuan luas lahan.

b. Daya dukung subsistem, menunjukan jumlah hewan yang agak kurang, persediaan makanan lebih banyak tetapi hanya cukup untuk dimakan.

c. Daya dukung optimum, jumlah hewan lebih rendah dan terdapat keseimbangan baik antara hewan dan persediaan makanan cukup baik.

d. Daya dukung sub optimum, dimana jumlah hewan lebih rendah lagi, persediaan makanan melebihi jumlah yang diperlukan.

Notohadiprawiro dalam Weol (2007), mengemukakan bahwa kemampuan lahan menyiratkan daya dukung lahan. Kemampuan lahan adalah mutu lahan yang dinilai secara menyeluruh dengan pengertian merupakan suatu pengenal majemuk lahan dan nilai kemampuan lahan berbeda untuk penggunaan yang berbeda. Dalam kaitanya dengan pemenuhan manusia, maka kemampuan lahan terjabarkan menjadi pengertian daya dukung lahan.

Imbangan tingkat pemanfaatan lahan dengan adanya daya dukung lahan menjadi ukuran kelayakan penggunaan lahan. Sebaliknya jika pemakaian lahan telah melampui kemampuan daya dukung lahan, maka pemanfaatan lahan tidak dipakai secara efektif. Dari uraian sebeluumnya, secara jelas dapat dikatakan bahwa daya kebutuhan manusia dalam bentuk penggunaan lahan, yang pada akhirnya tujuannya adalah memenuhi kebutuhan pangan dari masyarakat.

Soenarwoto dalam Weol (2007) dalam populasi manusia, daya dukung pada hakekatnya adalah daya dukung lingkungan alamiah, yaitu berdasarkan biomasa tumbuhan dan hewan yang dapat dikumpulkan dan ditangkap per satuan luas dan waktu di daerah itu. Dalam masyarakat agraris daya 
dukung akan lebih mudah dianalis dengan menggunakan daya dukung alamiah.

Daya dukung tergantung pada presentase lahan yang dapat dipakai untuk pertanian per satuan luas dan waktu. Makin besar prosentase lahan yang dipakai untuk pertanian makin besar daya dukungnya. Untuk menganalisis daya dukung dalam penelitian ini digunakan analisis tentang tekanan penduduk. Apabila terjadi kenaikan tekanan penduduk akan mendorong untuk memperluas lahan pertaniannya yang pada gilirannya usaha pertanian akan dipaksakan menggunakan lahan yang relative kurang subur.

\section{Tanaman Pangan dan Pertumbuhan Penduduk}

Tanaman pangan adalah segala jenis tanaman yang dapat menghasilkan karbohidrat dan protein. Tanaman pangan mencakup tanaman padi (padi sawah dan padi ladang), jagung, ubi kayu, ubi jalar, kacang tanah dan kacang kedelai.

Batasan untuk tanaman pangan adalah tanaman sumber karbohidrat dan protein, namun secara sempit tanaman pangan biasanya dibatasi pada kelompok tanaman yang berumur semusim. Batasan ini dimasa mendatang harus diperbarui karena akan menyebabkan sumber karbohidrat menjadi terbatas. Tanaman pangan sebaiknya memasukan jenis tanaman lain yang dapat menjadi sumber karbohidrat tanpa dibatasi pada kelompok tanaman semusim (Purwono dan Heni, 2007).

Pangan diperuntukkan bagi konsumsi manusia sebagai makanan atau minuman, termasuk bahan tambahan pangan, bahan baku pangan, dan bahan-bahan lain yang digunakan dalam proses penyiapan, pengolahan, dan atau pembuatan makanan atau minuman. Pangan merupakan sumber zat - zat dibutuhkan bagi pemeliharaan pertumbuhan dan proses metabolisme dalam tubuh. Cukupnya pangan bagi manusia didefinisikan sebagai kebutuhan harian yang memenuhi kebutuhan gizi yaitu sumber kalori atau energi yang berasal dari semua bahan pangan yang berfungsi untuk pertumbuhan, pemeliharaan dan penggantian jaringan serta sumber.

Basri (2010), Sebagian besar kalori dan protein yang kita makan berasal dari tumbuhan yaitu 70 kalori dan 50 protein terdapat pada padi, jagung, kacang - kacangan ubi - ubian . Apabila pangan diproduksi dalam jumlah yang cukup dan tersedia di tingkat desa atau masyarakat maka masalah kekurangan gizi dapat diatasi. Ketersediaan pangan lebih erat kaitanya dengan masalah penduduk. Lahan sebagai sumber pangan luasnya tetap sedangkan pertambahan penduduk terus bertambah.

Indonesia sebenarnya memiliki tujuan pembangunan ketahanan pangan yang sangat mulia, yaitu menjamin ketersediaan dan konsumsi pangan yang cukup, aman, bermutu dan bergizi seimbang pada tingkat rumah tangga, daerah, nasional sepanjang waktu dan merata melalui pemanfaatan sumber daya dan budaya lokal, teknologi inovatif, dan peluang masyarakat, serta memperkuat ekonomi pedesaan mengentaskan masyarakat dari kemiskinan. Dalam hal ini tidak berlebihan jika dikatakan bahwa pemenuhan pangan menjadi hak asasi setiap rakyat Indonesia dalam memuwujudkan sumber daya manusia yang berkualitas untuk melaksanakan pembangunan (Arifin, 2007).

Dalam program pemerintah yang tertuang dalam peraturan Menteri Pertanian No 43 Tahun 2009 tentang Ketahanan Pangan yaitu diversifikasi pangan, sebuah program yang mendorong masyarakat memvariasikan makanan pokok yang dikonsumsinya sehingga tidak terfokus pada satu jenis. Di Indonesia, diversifikasi dimaksudkan untuk menvariasikan konsumsi masyarakat agar tidak terfokus pada nasi.

Kebutuhan manusia akan pangan tidak bisa ditahan dan sampai saat ini tetap merupakan salah satu masalah yang harus diatasi oleh sektor pertanian. Dengan bertambahnya jumlah penduduk maka secara otomatis akan terjadi peningkatan kebutuhan akan pangan karena sesuai dengan kodratnya, manusia butuh makan untuk mempertahankan dan melanjutkan hidupnya. Sementara pertumbuhan antara pangan dan jumlah manusia jaul lebih cepat dibanding pertumbuhan pangan.

Pertumbuhan penduduk di daerah pedesaan mengakibatkan menurunnya nisbah lahan terhadap penduduk. karena sebagian besar penduduk tetap bekerja sebagai petani, penurunan nisbah tersebut berarti pula menurunya rata - rata luas lahan pertanian per petani. Populasi yang meningkat akan memerlukan lebih banyak pangan, hal ini akan menyebabkan daya dukung tanaman pangan akan terlampaui karena lingkungan sebagai sumber pangan memiliki keterbatasan. Jika pemanfaatan dan popu- 
lasi yang dapat didukung oleh tanaman pangan telah melewati batas kemampuan, akan terjadi ketidakseimbangan.

\section{Tekanan Penduduk Terhadap Lahan Pertanian}

Sejarah mencatat salah satu isi buku Malthus (1808) dalam Moerhar (2004), yang membahas tentang tekanan penduduk sehubungan dengan upaya pemenuhan kebutuhan pangan. Disebutkan bahwa pertumbuhan penduduk menyerupai sebuah deret ukur, sementara peningkatan produksi menyerupai deret hitung. Artinya pertumbuhan penduduk jauh lebih cepat dibandingkan dengan pertumbuhan produksi. Semakin lama pertumbuhan tersebut akan menjadi masalah kalau tidak dilakukan upaya upaya yang dapat mengatasinya.Walaupun teknologi sudah ditemui dan dianggap sementara dapat mengatasi masalah tekanan penduduk, tetapi harus tetap diwaspadai.

Dengan bertambahnya jumlah penduduk dari tahun ke tahun, maka sudah pasti akan terjadi penciutan pemilikan lahan. Hal ini terjadi karena proyek pembangunan atau pembukaan lahan baru tidak sebanding dengan pertambahan pengguna lahan.

Kerusakan sumber daya alam dan lingkungan hidup yang terjadi selama ini berkaitan erat dengan tingkat pertambahan penduduk dan pola penyebaran yang kurang seimbang dengan jumlah dan pola penyebaran sumber daya alam serta daya dukung lingkungan yang ada.( Moh.Soerjani dalam Weol, 2007).

Masalah kerusakan lingkungan yang paling kritis adalah tekanan penduduk terhadap sektor pertanian. Masalah ini terus meningkat sejalan dengan waktu karena adanya pertambahan penduduk dan dipakainya terus lahan pertanian untuk pengembangan di sektor non pertanian. Akibatnya, Pertumbuhan penduduk dan pemanfaatan lahan pertanian untuk pembangunan fisik akan mendorong masyarakat untuk membuka lahan - lahan pertanian baru yang menjadi salah satu penyebab bencana alam seperti longsor dan banjir.

Penurunan daya dukung lahan dipengaruhi oleh jumlah penduduk yang terus meningkat, luas lahan yang semakin berkurang, presentase jumlah petani dan luas lahan yang diperlukan untuk hidup layak. Tekanan penduduk banyak terjadi di wilayah yang mempunyai kemampuan lahan rendah. faktor - faktor yang mempengarui tekanan penduduk adalah struktur pekerjaan, kemampuan lahan dan kepadatan agraris (Ida Bagus Mantra, 2003).

Perubahan tersebut ditentukan oleh kebutuhan hidup manusia dan dapat menggangu fungsi lahan itu sendiri. Bentuk penguasaan lahan pada dasarnya adalah wujud nyata dari proses interaksi yang terjadi antara aktivitas - aktivitas dan meningkatkan taraf hidupnya. (Soerjani dalam Weol,2007).

Menurut Sitanala(2008) Tersedianya sumber daya lahan pertanian pangan yang berkelanjutan merupakan syarat untuk ketahanan pa-ngan nasional. Ketersediaan lahan pertanian pa-ngan berkaitan sangat dengan beberapa hal yaitu :

a. Potensi sumber daya lahan pertanian pangan,

b. Produktivitas lahan,

c. Fragmentasi lahan pertanian,

d. Skala luasan penguasaan lahan pertanian,

e. Sistem irigasi,

f. Lahan pertanian,

g. Konversi,

h. Pendapatan petani,

i. Kapasitas SDM pertanian serta,

j. Kebijakan di bidang pertanian.

\section{Analisis Daya Dukung Lahan}

\section{a. Perhitungan Kebutuhan Fisik Minimum}

Perhitungan Kebutuhan Fisik Minimum dalam suatu wilayah yang sama, daya dukung dapat berbeda karena cara pendekatannya yang berbeda. Untuk daerah - daerah yang sebagian besar penduduknya hidup dari sektor pertanian, daya dukung di hitung dari produksi bahan makanan.

Segi perhitungannya dapat dihitung dari Kebutuhan Fisik Minimum (KFM) yang di dasarkan atas kebutuhan kalori per orang per hari yaitu 2600 per orang per hari atau 265 kilogram beras per orang per tahun.

Pemahaman kalori sebagai dasar perhitungan atas pertimbangan bahwa untuk hidup sehat seseorang memerlukan sejumlah kalori tertentu yang berasal dari bahan makanan berbentuk bahan protein, lemak dan karbohidrat ditambah dengan mineral dan vitamin. Dengan dasar kalori ini, 
semua bahan makanan telah tercakup di dalamnya. Pertimbangan lain adalah karena hasil pertanian sebagian besar berupa karbohidrat seperti padi, jagung, ubi kayu, ubi jalar, kedelai dan kacang tanah yang merupakan sumber kalori terbesar dalam komposisibahan makanan (Odum dkk. dalam Moniaga, 2011).

Nilai kebutuhan pokok fisik minimum adalah nilai yang menunjukkan seseorang dapat hidup secara normal, sehingga dapat bekerja untuk memenuhi kebutuhan hidupnya. Untuk itu diperlukan bahan makanan sebagai kebutuhan pokok manusia.

b. Luas lahan tanaman pangan yang diperlukan per kapita untuk swasembada pangan

Luas lahan tanaman pangan yang dibutuhkan per kapita untuk swasembada (K), merupakan salah satu komponen yang sangat penting dalam perhitungan tingkat daya dukung lahan pertanian. Niai $\mathrm{K}$ diperhitungkan dengan membagi nilai kebutuhan fisik minimum (KFM) dengan produksi tanaman pangan per tahun yang tadinya dalam satuan ton, dikonversi menjadi kalori kemudian dikonversi lagi menjadi kg beras untuk komoditi padi sedangkan komiditi lain tidak. Semakin kecil K maka tingkat daya dukung lahan pertanian akan semakin baik. Luas lahan tanaman pangan yang dibutuhkan per kapita untuk swasembada pangan, nilainya selalu berubah - ubah menurut waktu dan ruang karena dipengarui oleh KFM dan kemampuan lahan untuk memproduksi tanaman pangan.

\section{c. Luas Panen Tanaman Pangan Yang Tersedia Per Kapita}

Komponen lain yang penting dalam perhitungan daya dukung lahan pertanian adalah luas panen tanaman pangan yang tersedia per kapita (X). Nilai X ini diperoleh dari luas tanaman pangan pada suatu daerah dibagi jumlah penduduk pada daerah tersebut. Luas panen tanaman pangan ini nilainya selalu berubah ubah baik antara daerah maupun antara waktu. Nilai $\mathrm{X}$ ini merupakan kebalikan dari nilai K, karena semakin besar nilai X maka akan semakin baik tingkat daya dukung lahan pertanian di daerah tersebut.

\section{Rumusan Masalah}

Seberapa besar daya dukung lahan pertanian dalam memenuhi kebutuhan pangan dari penduduk seiring dengan bertambahnya penduduk dari tahun ke tahun di Kabupaten Minahasa Selatan.

\section{Tujuan Penelitian}

Untuk mengetahui besarnya daya dukung lahan pertanian yang ada di Kabupaten Minahasa Selatan di kaitkan dengan jumlah penduduk.

\section{Manfaat Penelitian}

Dari hasil penelitian ini diharapakan dapat memberikan informasi dan bahan masukan tentang besarnya daya dukung tanaman.

\section{METODE PENELITIAN}

\section{Tempat dan Waktu Penelitian}

Penelitian ini dilaksanakan di Kabupaten Minahasa Selatan bertempat di Badan Pusat Statistik Kabupaten Minahasa Selatan dan instansi lembaga yang terkait. Penelitian ini dilaksanakan bulan Maret - Juni 2015.

\section{Metode Pengambilan Data}

Metode pengumpulan data dalam penelitian ini adalah berupa data sekunder yang diperoleh dari Badan PusatStatistik dan intansi/lembaga yang terkait dengan penelitian ini.

\section{Konsep Pengukuran Variabel}

a. Luas Panen tanaman pangan adalah jumlah luas dari lahan yang ditanami dengan tanaman pangan dalam satu tahun (ha).

b. Produksi tanaman pangan di masing masing daerah $(\mathrm{kg})$.

c. Luas lahan per kapita yang diperlukan untuk swasembada pangan (ha).

d. Jumlah kalori tanaman pangan adalah jumlah kandungan kalori setara kilogram 
beras masing - masing tanaman pangan. Dimana 1 Kilogram beras sebesar 3.610 kalori, 1 kilogram Jagung sebesar 3.600,1 kilogram ubi kayu sebesar 1.460 kalori, 1 kilogram ubi jalar sebesar 1.230 kalori, 1 kilogram kacang tanah sebesar 4.520 kalori dan 1 kilogram kedelai 3.310 kalori.

e. Jumlah penduduk ( jiwa ).

\section{Metode Analisis Data}

Penelitian ini mengunakan analisis data yang menentukan tingkat daya dukung lahan pertanian tanaman pangan digunakan rumus dari konsep gabungan atas teori Odum, Christeiler, Ebenezer Howard dan Issard dalam Soehardjo dan Tukiran (1990) dalam Moniaga (2011), yaitu

$$
\text { (1) } \Phi=\frac{X}{\mathrm{~K}}
$$

dimana : $\Phi=$ Tingkat daya dukung lahan pertanian $\mathrm{X}=$ Luas panen tanaman pangan perkapita $\mathrm{K}=$ Luas lahan untuk swasembada pangan dengan :

$$
X=\frac{\text { Luas Panen (Ha) }}{\text { Jumlah Penduduk (Jiwa) }}
$$

$$
x=\frac{\text { Kebutuhan Fisik Minimum (KFM) }}{\text { Produksi Tanaman Pangan ha/tahun }}
$$

atau $\Phi=\frac{\text { Luas Panen } \times \text { Produksi } / \text { hektar } / \text { thn }}{\text { Jumlah Penduduk x KFM }}$

Dimana , KFM setara dengan 2600 Kalori per kapita per hari atau 265 kilogram beras per orang per tahun.

\section{HASIL DAN PEMBAHASAN}

\section{Keadaan Geografis}

Minahasa Selatan adalah salah satu Kabupaten di Provinsi Sulawesi Utara. Ibukota Kabupaten
Minahasa Selatan adalah Amurang, berjarak sekitar $64 \mathrm{~km}$ dari Manado, Ibukota Provinsi Sulawesi Utara.

Adapun batas-batasnya adalah sebagai berikut :

a. Sebelah Utara dengan Kabupaten Minahasa;

b. Sebelah Timur dengan Kabupaten Minahasa Tenggara;

c. Sebelah Selatan dengan Kabupaten Bolaang Mongondow;

d. Sebelah Barat dengan Laut Sulawesi.

Luas Kabupaten Minahasa Selatan adalah 1.484,47 $\mathrm{Km}^{2}$ Kabupaten Minahasa Selatan terdiri atas 17 Kecamatan. Sebagian besar wilayah Minahasa Selatan memiliki topografi bergunung gunung yang membentang dari utara ke selatan.

\section{Penduduk}

Data tahun 2014 dari Badan Pusat Statistik Kabupaten Minahasa Selatan Jumlah penduduk Minahasa Selatan adalah 200.072 jiwa. Tabel 2 menunjukan bahwa jumlah penduduk terbesar terdapat pada Kecamatan Tengah yaitu 17.444 dengan kepadatan penduduk 139,12 jiwa dan jumlah penduduk terkecil terdapat pada kecamatan kumelembuai 6553 dengan kepadatan penduduk 172,95 jiwa.

\section{Tata Guna Lahan}

Tata guna lahan merupakan usaha untuk mengatur dan memanfaatkan lahan serta sumber dayanya agar lahan tersebut dapat dimanfaatkan sebesar - besarnya untuk kesejahteraan masyarakat. Tanah atau lahan selalu mempunyai kaitan yang erat dengan pertanian.pemanfaatan lahan di Kabupaten Minahasa Selatan di bagi dalam 2 kategori yaitu untuk lahan sawah sebesar 5.234 ha, Lahan bukan sawah yang terbagi atas pekarangan sebesar 10.422 ha, untuk tegal / kebun sebesar 54.621 ha, perkebunan 30.373 ha, Lahan yang sementara tidak diusahakan sebesar 
18.375 ha, kolam 572 ha, tanah kayu kayuan 18.375 ha, dan lain - lain 20.142 ha. Dapat dilihat bahwa sebagian besar wilayah Kabupaen Minahasa Selatan adalah lahan bukan sawah dengan luas sebesar 159.165 hektar, yang banyak dimanfaatkan sebagai lahan perkebunan sebesar 30.373 hektar.

\section{Daya Dukung Lahan Pertanian}

a. Luas lahan tanaman pangan yang diperlukan per kapita untuk swasembada panganLuas lahan tanaman pangan yang dibutuhkan per kapita untuk swasembada (K), merupakan salah satu komponen yang sangat penting dalam perhitungan tingkat daya dukung lahan pertanian. Untuk itu daerah - daerah yang memiliki nilai $\mathrm{K}$ tinggi diperlukan usaha untuk menurunkan angka tersebut melalui pening- katan produktivitas tanaman pangan atau memperluas areal tanaman pangan.

Tabel 4 menunjukkan bahwa luas lahan tanaman pangan yang dibutuhkan per kapita untuk swasembada pangan bagi setiap penduduk di Kabupaten Minahasa Selatan Tahun 2010 - 2014 rata - rata sebesar 0,088 ha/orang. Dari perhitungan yang diperoleh, nilai $\mathrm{K}$ ini bervariasi dimana nilai terendah 0,053 ha/orang pada Kecamatan Modoinding dan nilai tertinggi $0,149 \mathrm{ha} /$ orang pada Kecamatan Tatapaan. Jadi Kecamatan Modoinding memiliki daya dukung lahan pertanian yang lebih baik dibandingkan Kecamatan Kecamatan lain yang ada di Kabupaten Minahasa Selatan, Karena semakin kecil nilai K maka kemampuan daya dukung lahan pertanian akan semakin besar. Untuk itu sangat diperlukan usaha untuk menurunkan nilai $\mathrm{K}$, seperti peningkatan produktivitas tanaman pangan atau memperluas areal tanaman pangan.

\section{Tabel 1. Luas Wilayah Kabupaten Minahasa Selatan menurut Kecamatan Tahun 2014}

\begin{tabular}{clcc}
\hline No & Kecamatan & Luas Wilayah $\left(\mathrm{Km}^{2}\right)$ & Presentase \\
& & 46,98 & 3,16 \\
\hline 1 & Modoinding & 129,48 & 8,72 \\
2 & Tompaso Baru & 143,98 & 9,70 \\
3 & Maesaan & 102,44 & 6,90 \\
4 & Ranoyapo & 15,11 & 1,02 \\
5 & Motoling & 37,89 & 2,55 \\
6 & Kumelembuai & 128,40 & 8,65 \\
7 & Motoling Barat & 50,44 & 3,40 \\
8 & Motoling Timur & 104,58 & 7,05 \\
9 & Sinonsayang & 125,39 & 8,45 \\
10 & Tenga & 69,45 & 4,68 \\
11 & Amurang & 103,40 & 6,97 \\
12 & Amurang Barat & 152,73 & 10,29 \\
13 & Amurang Timur & 51,91 & 3,50 \\
14 & Tareran & 35,84 & 2,41 \\
15 & Sulta & 78,26 & 5,27 \\
16 & Tumpaan & 108,19 & 7,29 \\
17 & Tatapaan & $1.484,47$ & 100,00 \\
\hline & Jumlah / Total & & \\
\hline
\end{tabular}

Sumber : BPS Minsel 
Tabel 2. Luas dan Kepadatan Penduduk Menurut Kecamatan Tahun 2014

\begin{tabular}{llrrr} 
No. Kecamatan & \multicolumn{1}{c}{ Luas $\left(\mathrm{Km}^{2}\right)$} & \multicolumn{1}{c}{ Penduduk } & Kepadatan Penduduk \\
\hline 1 & Modoinding & 46,98 & 11.822 & 251,64 \\
2 & Tompasobaru & 129,48 & 11.819 & 91,28 \\
3 & Maesaan & 143,98 & 9.832 & 68,29 \\
4 & Ranoyapo & 102,44 & 12.089 & 118,01 \\
5 & Motoling & 15,11 & 7.225 & 478,16 \\
6 & Kumelembuai & 37,89 & 6.553 & 172,95 \\
7 & Motoling barat & 128,40 & 7.706 & 60,02 \\
8 & Motoling Timur & 50,44 & 8.995 & 178,33 \\
9 & Sinonsayang & 104,58 & 15.283 & 146,14 \\
10 & Tenga & 125,39 & 17.444 & 139,12 \\
11 & Amurang & 69,45 & 17.112 & 246,39 \\
12 & Amurang Barat & 103,40 & 15.345 & 148,40 \\
13 & Amurang Timur & 152,73 & 14.270 & 93,43 \\
14 & Tareran & 51,91 & 12.261 & 236,20 \\
15 & Sulta & 35,84 & 7.226 & 201,62 \\
16 & Tumpaan & 78,26 & 16.061 & 205,23 \\
17 & Tatapaan & 108,19 & 9.029 & 83,46 \\
\hline & & $1.484,47$ & 200.072 & 134,78 \\
\hline
\end{tabular}

Sumber : BPS Minsel

\section{Produksi dan Luas Panen}

Produksi pertanian yang tinggi dipengaruhi banyak faktor, diantaranya faktor kesuburan tanah, ada tidaknya serangan hama dan penyakit, teknik budidaya dan pemeliharaan yang baik.

\section{b. Luas Panen Tanaman Pangan Yang Terse- dia Per Kapita}

Komponen lain yang penting dalam perhitungan daya dukung lahan pertanian adalah luas panen tanaman pangan yang tersedia per kapita ( $X$ ). Nilai $X$ ini diperoleh dari luas tanaman pangan pada suatu daerah dibagi jumlah penduduk pada daerah tersebut. Luas panen tanaman pangan ini nilainya selalu berubah-ubah baik antara daerah maupun antara waktu. Nilai $\mathrm{X}$ ini merupakan kebalikan dari nilai $\mathrm{K}$, karena semakin besar nilai X maka akan semakin baik tingkat daya dukung lahan pertanian di daerah tersebut. Dari Tabel 5 menunjukan bahwa nilai terbesar X terdapat pada Kecamatan Maesaan untuk terkecil pada Kecamatan Amurang dan Modoinding, hal ini berarti luas lahan untuk swasembada pangan meningkat maka luas panen pun harus di tingkatkan yaitu dengan penambahan areal luas tanam tanaman pangan.

Dari Tahun 2010 sampai dengan 2014 rata - rata luas panen tanaman pangan yang tersedia per kapita di Kabupaten Minahasa Selatan sebesar $0,032 \mathrm{ha} /$ orang. Nilai X tertinggi 0,083 ha/orang yaitu pada Kecamatan Maesaan. Dengan nilai tertinggi Kecamatan Maesaan akan sangat mempengarui daya dukung lahan pada daerah tersebut sehingga bisa swasembada pangan memberikan kehidupan yang layak bagi penduduknya. Nilai terendah pada Kecamatan Amurang dan Modoinding yaitu 0,006 ha/orang. Akibatnya Kecamatan tersebut akan sangat mempengarui tingkat daya dukung 
lahan dan akan berdampak pada swasembada pangan pada daerah tersebut dan tidak dapat memberikan kehidupan yang layak .

Tabel 5 menunjukkan Kecamatan Maesaan merupakan daerah yang memberikan luas panen tanaman pangan yang terbesar dari semua Kecamatan yang ada di Kabupaten Minahasa Selatan. Kecamatan Modoinding merupakan Kecamatan yang kurang dalam membudidayakan tanaman pangan, hanya tanaman hortikultura yang banyak dibudidayakan. Kecamatan Amurang tidak dapat memberikan kontribusi luas panen tanaman pangan karena daerah tersebut lahan pertaniannya telah banyak di alih fungsikan menjadi bangunan, industri, dan pemukiman.
Tabel 3. Produksi dan Luas Panen per Komoditi di Kabupaten Minahasa Selatan Tahun 2014

\begin{tabular}{lrrr} 
Komoditas & \multicolumn{1}{c}{$\begin{array}{c}\text { Luas } \\
\text { tanam }(\text { ha }\end{array}$} & $\begin{array}{c}\text { Luas } \\
\text { panen }( \\
\text { ha })\end{array}$ & $\begin{array}{c}\text { Produksi } \\
(\mathrm{kg})\end{array}$ \\
\hline Padi sawah & 13.107 & 13.495 & 71.949 \\
Padi Ladang & 2.000 & 1.895 & 4.950 \\
Jagung & 23.182 & 23.004 & 90.695 \\
Kedelai & - & 102 & 148 \\
Kacang & 534 & 532 & 752 \\
Tanah & & & \\
Ubi jalar & 134 & 185 & 1.800 \\
Ubi kayu & 270 & 272 & 13.315 \\
\hline Sumber:BPS & & &
\end{tabular}

Sumber : BPS Minsel

Tabel 4. Rata - Rata Luas Lahan Tanaman Pangan Per Kapita Untuk Swasembada Pangan Di Kabupaten Minahasa Selatan Tahun 2010-2014 ( K )

\begin{tabular}{clllllll}
\hline No & Kecamatan & 2010 & 2011 & 2012 & 2013 & 2014 & $\begin{array}{c}\text { Rata }- \\
\text { Rata }\end{array}$ \\
\hline 1 & Modoinding & 0,0525 & 0,0525 & 0,0541 & 0,0540 & 0,0541 & 0,053 \\
2 & Tompasobaru & 0,1003 & 0,1030 & 0,0743 & 0,1083 & 0,1014 & 0,097 \\
3 & Maesaan & 0,0921 & 0,1028 & 0,1067 & 0,1076 & 0,1085 & 0,104 \\
4 & Ranoyapo & 0,0753 & 0,0747 & 0,0752 & 0,0757 & 0,0768 & 0,076 \\
5 & Motoling & 0,0769 & 0,0763 & 0,0768 & 0,1094 & 0,0896 & 0,086 \\
6 & Kumelembuai & 0,0763 & 0,0753 & 0,0759 & 0,0773 & 0,0582 & 0,073 \\
7 & Motoling barat & 0,0775 & 0,0993 & 0,0769 & 0,0786 & 0,0528 & 0,077 \\
8 & Motoling Timur & 0,0787 & 0,0799 & 0,0791 & 0,0809 & 0,0815 & 0,080 \\
9 & Sinonsayang & 0,0893 & 0,0779 & 0,0783 & 0,0583 & 0,0610 & 0,073 \\
10 & Tenga & 0,0769 & 0,0761 & 0,0756 & 0,1119 & 0,0789 & 0,084 \\
11 & Amurang & 0,0618 & 0,0753 & 0,0755 & 0,0808 & 0,0376 & 0,066 \\
12 & Amurang Barat & 0,1014 & 0,1044 & 0,1083 & 0,1159 & 0,1091 & 0,108 \\
13 & Amurang Timur & 0,1020 & 0,1058 & 0,0747 & 0,1087 & 0,1086 & 0,100 \\
14 & Tareran & 0,0763 & 0,0639 & 0,0856 & 0,0759 & 0,0775 & 0,076 \\
15 & Sulta & 0,0764 & 0,1144 & 0,0853 & 0,0773 & 0,0942 & 0,090 \\
16 & Tumpaan & 0,1755 & 0,0744 & 0,0751 & 0,0523 & 0,1782 & 0,111 \\
17 & Tatapaan & 0,2076 & 0,1058 & 0,1105 & 0,1100 & 0,2115 & 0,149 \\
\hline & & \multicolumn{7}{c}{ Rata - Rata } & & & 0,088 \\
\hline
\end{tabular}

Sumber : Data di olah dari lampiran 1 
Tabel 5. Rata -Rata Luas Panen Tanaman Pangan Di Kabupaten Minahasa Selatan Tahun 2010 2014 ( X )

\begin{tabular}{rlrrrrrr}
\hline No & \multicolumn{1}{c}{ Kecamatan } & 2010 & \multicolumn{1}{c}{2011} & 2012 & 2013 & 2014 & \multicolumn{1}{c}{$\begin{array}{c}\text { Rata }- \\
\text { Rata }\end{array}$} \\
\hline 1 & Modoinding & 0,0103 & 0,0036 & 0,0063 & 0,0042 & 0,0071 & 0,006 \\
2 & Tompasobaru & 0,0661 & 0,0656 & 0,0618 & 0,0597 & 0,0648 & 0,064 \\
3 & Maesaan & 0,0843 & 0,0841 & 0,0712 & 0,0895 & 0,0847 & 0,083 \\
4 & Ranoyapo & 0,0626 & 0,0607 & 0,0621 & 0,0609 & 0,06 & 0,061 \\
5 & Motoling & 0,0209 & 0,0154 & 0,028 & 0,0256 & 0,0215 & 0,022 \\
6 & Kumelembuai & 0,0116 & 0,0197 & 0,0132 & 0,011 & 0,0109 & 0,013 \\
7 & Motoling barat & 0,0142 & 0,0175 & 0,0151 & 0,0144 & 0,0143 & 0,015 \\
8 & Motoling Timur & 0,0085 & 0,0111 & 0,0089 & 0,0054 & 0,0081 & 0,008 \\
9 & Sinonsayang & 0,0353 & 0,0298 & 0,0326 & 0,028 & 0,0347 & 0,032 \\
10 & Tenga & 0,0433 & 0,0485 & 0,0413 & 0,0423 & 0,0419 & 0,043 \\
11 & Amurang & 0,0055 & 0,0073 & 0,0048 & 0,0048 & 0,0052 & 0,006 \\
12 & Amurang Barat & 0,044 & 0,0272 & 0,0407 & 0,0499 & 0,0431 & 0,041 \\
13 & Amurang Timur & 0,0233 & 0,0218 & 0,0216 & 0,0237 & 0,0213 & 0,022 \\
\hline 14 & Tareran & 0,0253 & 0,0157 & 0,0214 & 0,0239 & 0,0249 & 0,022 \\
15 & Sulta & 0,0191 & 0,0152 & 0,0191 & 0,0188 & 0,0188 & 0,018 \\
16 & Tumpaan & 0,0268 & 0,0265 & 0,0206 & 0,0209 & 0,0241 & 0,024 \\
17 & Tatapaan & 0,0714 & 0,0568 & 0,051 & 0,0485 & 0,066 & 0,059 \\
\hline & & & & Rata - Rata & & & 0,032 \\
\hline
\end{tabular}

Sumber : Data diolah dari lampiran 1

\section{Daya Dukung Lahan Pertanian Tanaman Pangan}

Perhitungan daya dukung lahan pertanian tanaman pangan untuk tiap Kecamatan di Kabupaten Minahasa Selatan tahun 2010 - 2014. Variasi tingkat daya dukung lahan pertanian disebabkan oleh produksi tanaman pangan dan jumlah penduduk yang bervariasi pula. tingkat daya dukung lahan pertanian tanaman tanaman pangan di Kabupaten Minahasa Selatan dapat dilihat pada Tabel 6. Dari Tabel 6 dilihat Kecamatan Tompasobaru, Maesaan, dan Ranoyapo tingkat daya dukung tanaman padi nilainya dari tahun 2010 - 2014 lebih dari Kecamatan lainya. Pada Kecamatan Modoinding tidak terdapat nilai karena Kecamatan tersebut hanya tanaman hortikultura dan tanaman pangan lainnya. Kecamatan
Amurang produksi tanaman pangan sangat kurang akibat Kecamatan tersebut,lahan yang merupakan lahan pertanian telah di alih fungsikan menjadi perumahan, industri dan lain - lain. Kecamatan lainnya dari tahun 2010 2014 bervariasi mengalami penurunan dan kenaikan.

Tabel 7 menunjukan daya dukung lahan pertanian tanaman jagung, Kecamatan Maesaan, Tompasobaru dan Amurang Barat dari tahun 2010 - 2014 tetap memiliki nilai lebih besar dari Kecamatan dari tahun ke tahun. Pada Kecamatan Tatapaan dilihat pada tahun 2010 nilainya naik sangat besar pada tahun 2011 dan pada tahun 2014 nilainya turun sama dengan pada tahun 2010. 
Tabel. 6. Daya Dukung Lahan Pertanian Tanaman Padi Tahun 2010 - 2014

\begin{tabular}{clccccc}
\hline No & \multicolumn{1}{c}{ Kecamatan } & 2010 & 2011 & 2012 & 2013 & 2014 \\
\hline 1 & Modoinding & 0,00000 & 0,00000 & 0,00000 & 0,00000 & 0,00000 \\
2 & Tompasobaru & 2,60181 & 2,37669 & 2,66889 & 2,46235 & 2,56130 \\
3 & Maesaan & 2,81853 & 3,27674 & 2,90836 & 3,01139 & 2,84032 \\
4 & Ranoyapo & 2,88239 & 2,90261 & 3,11702 & 3,03073 & 2,70428 \\
5 & Motoling & 0,31112 & 0,33455 & 0,43847 & 0,42309 & 0,26823 \\
6 & Kumelembuai & 0,14527 & 0,06855 & 0,08482 & 0,12123 & 0,09834 \\
7 & Motoling barat & 0,14267 & 0,23863 & 0,32348 & 0,31630 & 0,14123 \\
8 & Motoling Timur & 0,06270 & 0,06109 & 0,07020 & 0,07104 & 0,05678 \\
9 & Sinonsayang & 0,75801 & 0,62558 & 0,66085 & 0,55644 & 0,70757 \\
10 & Tenga & 1,32037 & 1,52928 & 1,41869 & 1,34912 & 1,23915 \\
11 & Amurang & 0,00000 & 0,00939 & 0,02352 & 0,03978 & 0,00000 \\
12 & Amurang Barat & 0,08040 & 0,08090 & 0,15557 & 0,21229 & 0,06874 \\
13 & Amurang Timur & 0,39830 & 0,29864 & 0,46105 & 0,59339 & 0,31710 \\
14 & Tareran & 0,53169 & 0,33904 & 0,53278 & 0,75960 & 0,51096 \\
15 & Sulta & 0,08983 & 0,05783 & 0,09709 & 0,08822 & 0,09512 \\
16 & Tumpaan & 1,12379 & 0,79374 & 0,92909 & 0,86628 & 0,96321 \\
17 & Tatapaan & 2,10429 & 1,88348 & 1,60399 & 1,30110 & 1,86167 \\
\hline
\end{tabular}

Sumber : Diolah dari lampiran 1

Tabel 7. Daya Dukung Lahan Pertanian Tanaman Jagung Tahun 2010 - 2014

\begin{tabular}{clccccc}
\hline No & Kecamatan & 2010 & 2011 & 2012 & 2013 & 2014 \\
\hline 1 & Modoinding & 0,52913 & 0,23249 & 0,46776 & 0,28526 & 0,52913 \\
2 & Tompasobaru & 2,51796 & 2,85993 & 2,55821 & 2,34893 & 2,51796 \\
3 & Maesaan & 3,75488 & 3,08607 & 2,83603 & 4,15039 & 3,75488 \\
4 & Ranoyapo & 1,85170 & 1,71847 & 1,99564 & 1,87307 & 1,85170 \\
5 & Motoling & 1,37825 & 0,83561 & 1,63173 & 1,38593 & 1,37825 \\
6 & Kumelembuai & 0,76298 & 1,55960 & 1,01197 & 0,77422 & 0,76298 \\
7 & Motoling barat & 1,01507 & 1,16215 & 0,88434 & 0,81197 & 1,01507 \\
8 & Motoling Timur & 0,60054 & 0,81004 & 0,64010 & 0,33874 & 0,60054 \\
9 & Sinonsayang & 1,97703 & 1,62039 & 1,94485 & 1,73712 & 1,97703 \\
10 & Tenga & 1,90456 & 2,12853 & 2,02465 & 1,87208 & 1,90456 \\
11 & Amurang & 0,44248 & 0,59095 & 0,37538 & 0,33349 & 0,44248 \\
12 & Amurang Barat & 3,70917 & 2,17861 & 3,32133 & 3,94125 & 3,70917 \\
13 & Amurang Timur & 1,42461 & 1,38544 & 1,27767 & 1,26476 & 1,42461 \\
14 & Tareran & 1,50334 & 1,22821 & 1,19387 & 1,16116 & 1,50334 \\
15 & Sulta & 1,52715 & 1,14264 & 1,47289 & 1,51876 & 1,52715 \\
16 & Tumpaan & 0,09330 & 1,33585 & 0,77046 & 0,74603 & 0,09330 \\
17 & Tatapaan & 0,30880 & 2,16056 & 1,93774 & 2,23917 & 0,30880 \\
\hline Sumber
\end{tabular}

Sumber : Diolah dari lampiran 1 
Tabel 8. Daya Dukung Lahan Pertanian Tanaman Ubi Kayu Tahun 2010 - 2014

\begin{tabular}{clccccc} 
No Kecamatan & 2010 & 2011 & 2012 & 2013 & 2014 \\
\hline 1 & Modoinding & 0,00000 & 0,00000 & 0,00000 & 0,00000 & 0,00000 \\
2 & Tompasobaru & 0,03160 & 0,03309 & 0,04151 & 0,03840 & 0,03658 \\
3 & Maesaan & 0,00000 & 0,03800 & 0,06920 & 0,06932 & 0,06071 \\
4 & Ranoyapo & 0,03242 & 0,00689 & 0,01530 & 0,01523 & 0,01858 \\
5 & Motoling & 0,02593 & 0,03958 & 0,05903 & 0,05940 & 0,07368 \\
6 & Kumelembuai & 0,03573 & 0,02753 & 0,02745 & 0,02799 & 0,03428 \\
7 & Motoling barat & 0,03711 & 0,02651 & 0,05263 & 0,04513 & 0,06349 \\
8 & Motoling Timur & 0,02738 & 0,01880 & 0,01631 & 0,02298 & 0,01591 \\
9 & Sinonsayang & 0,00852 & 0,02833 & 0,02682 & 0,04309 & 0,05114 \\
10 & Tenga & 0,03374 & 0,02981 & 0,03196 & 0,03672 & 0,03422 \\
11 & Amurang & 0,03509 & 0,01627 & 0,01244 & 0,01214 & 0,01672 \\
12 & Amurang Barat & 0,03271 & 0,02871 & 0,02308 & 0,02416 & 0,01333 \\
13 & Amurang Timur & 0,02681 & 0,02551 & 0,02388 & 0,02473 & 0,02728 \\
14 & Tareran & 0,01541 & 0,02321 & 0,02145 & 0,00654 & 0,02146 \\
15 & Sulta & 0,03961 & 0,03143 & 0,03665 & 0,01967 & 0,00852 \\
16 & Tumpaan & 0,03096 & 0,02622 & 0,02858 & 0,00639 & 0,01015 \\
17 & Tatapaan & 0,03813 & 0,05680 & 0,05413 & 0,00904 & 0,02045 \\
\hline
\end{tabular}

Sumber : Diolah dari lampiran 1

Tabel 9. Daya Dukung Lahan Pertanian Tanaman Ubi Jalar Tahun 2010-2014

\begin{tabular}{clccccc}
\hline \multirow{2}{*}{ No } & \multicolumn{1}{c}{ Kecamatan } & 2010 & 2011 & 2012 & 2013 & 2014 \\
\hline 1 & Modoinding & 0,01505 & 0,02108 & 0,01986 & 0,01563 & 0,02082 \\
2 & Tompasobaru & 0,00949 & 0,01019 & 0,00999 & 0,01077 & 0,00927 \\
3 & Maesaan & 0,01285 & 0,01320 & 0,01115 & 0,01116 & 0,01114 \\
4 & Ranoyapo & 0,00520 & 0,00506 & 0,00532 & 0,00529 & 0,00829 \\
5 & Motoling & 0,01368 & 0,00833 & 0,01751 & 0,02526 & 0,02397 \\
6 & Kumelembuai & 0,01364 & 0,00901 & 0,00807 & 0,00695 & 0,00414 \\
7 & Motoling barat & 0,01117 & 0,00403 & 0,01172 & 0,01300 & 0,01895 \\
8 & Motoling Timur & 0,01149 & 0,01079 & 0,01035 & 0,00820 & 0,01009 \\
9 & Sinonsayang & 0,00472 & 0,00505 & 0,00591 & 0,00000 & 0,00000 \\
10 & Tenga & 0,00572 & 0,00648 & 0,00684 & 0,00732 & 0,00837 \\
11 & Amurang & 0,00734 & 0,00628 & 0,00666 & 0,00650 & 0,00695 \\
12 & Amurang Barat & 0,00713 & 0,00974 & 0,01025 & 0,01316 & 0,00952 \\
13 & Amurang Timur & 0,00519 & 0,00379 & 0,00464 & 0,00905 & 0,00321 \\
14 & Tareran & 0,00794 & 0,00563 & 0,00893 & 0,00597 & 0,00893 \\
15 & Sulta & 0,00550 & 0,00725 & 0,00756 & 0,00247 & 0,00000 \\
16 & Tumpaan & 0,00680 & 0,00607 & 0,00642 & 0,00171 & 0,00455 \\
17 & Tatapaan & 0,01277 & 0,01337 & 0,01208 & 0,00104 & 0,00508 \\
\hline
\end{tabular}

Sumber : Diolah dari lampiran 1 
Dari Tabel 8 daya dukung lahan pertanian tanaman ubi kayu, Kecamatan Maesaan dan Motoling dilihat dari tahun ke tahun mengalami kenaikan dan Kecamatan Sulta dari tahun ke tahun mengalami penurunan. Sedangkan Kecamatan lainya bervariasi dari tahun ke tahun ada yang naik ada yang turun.

Pada Tabel 9 Kecamatan Sinonsayang tahun 2013 dan tahun 2014 nilainya tidak ada atau pada tahun tersebut tidak menanam, begitu juga dengan Kecamatan Sulta pada tahun 2014. Dari tahun 2010 2014 naik turun nilai dari tahun ke tahun Kecamatan bervariasi Pada Tabel 10 daya dukung lahan pertanian tanaman kacang tanah, nilainya dari tahun 2010 2014 bervariasi. Pada tahun 2014 Kecamatan Kumelembuai, Motoling barat, Amurang dan
Tumpaan pada tahun 2013 nilainya tidak ada atau tidak menanam tanaman kacang tanah pada tahun tersebut. Akibatnya bisa mempengaruhi daya dukung lahan. Dari Tabel 11 daya dukung lahan pertanian tanaman kedelai, hanya beberapa Kecamatan yang bercocok tanam kedelai yaitu Tompasobaru, Maesaan, Motoling, Sinonsayang, Tengah, Amurang Barat, Amurang Timur dan Tatapaan. Kecamatan lainya tidak. Adapun Kecamatan Tengah, Sinonsayang, Tompasobaru, Motoling tidak tiap tahun bercocok tanam kedelai.

Tabel 12 menunjukan bahwa rata - rata tingkat daya dukung lahan pertanian per Kecamatan terendah terdapat pada Kecamatan Modoinding yaitu sebesar 0,076 dan tertinggi pada Kecamatan Maesaan yaitu sebesar 1,113 .

Tabel 10. Daya Dukung Lahan Pertanian Tanaman Kacang Tanah Tahun 2010 - 2014

\begin{tabular}{clccccc}
\hline No & \multicolumn{1}{c}{ Kecamatan } & 2010 & 2011 & 2012 & 2013 & 2014 \\
\hline 1 & Modoinding & 0,03287 & 0,02524 & 0,02953 & 0,03019 & 0,03425 \\
2 & Tompasobaru & 0,03848 & 0,02227 & 0,01081 & 0,01652 & 0,01128 \\
3 & Maesaan & 0,07163 & 0,13185 & 0,10712 & 0,07671 & 0,07218 \\
4 & Ranoyapo & 0,01344 & 0,04831 & 0,02229 & 0,00832 & 0,01221 \\
5 & Motoling & 0,01300 & 0,01258 & 0,11724 & 0,11008 & 0,12459 \\
6 & Kumelembuai & 0,01755 & 0,02292 & 0,01487 & 0,00217 & 0,00000 \\
7 & Motoling barat & 0,00937 & 0,01306 & 0,00922 & 0,00247 & 0,00000 \\
8 & Motoling Timur & 0,01111 & 0,01373 & 0,01358 & 0,00428 & 0,00424 \\
9 & Sinonsayang & 0,02237 & 0,01316 & 0,01084 & 0,01309 & 0,01060 \\
10 & Tenga & 0,01949 & 0,01386 & 0,00493 & 0,01342 & 0,00983 \\
11 & Amurang & 0,00685 & 0,00703 & 0,00406 & 0,00170 & 0,00000 \\
12 & Amurang Barat & 0,02142 & 0,01471 & 0,00664 & 0,03285 & 0,00993 \\
13 & Amurang Timur & 0,05869 & 0,05826 & 0,04894 & 0,02574 & 0,01769 \\
14 & Tareran & 0,01455 & 0,01571 & 0,02291 & 0,00506 & 0,00816 \\
15 & Sulta & 0,01058 & 0,01208 & 0,02787 & 0,01191 & 0,00527 \\
16 & Tumpaan & 0,01419 & 0,01049 & 0,00977 & 0,00000 & 0,00119 \\
17 & Tatapaan & 0,04174 & 0,04941 & 0,06304 & 0,04434 & 0,03007 \\
\hline
\end{tabular}

Sumber : Diolah dari lampiran 1

Maka dengan nilai rata - rata 0,414 tingkat daya dukung lahan pertanian di Kabupaten dapat dikatakan bahwa Kabupaten Minahasa Selatan belum mampu swasembada pangan.

Tabel 13 menunjukan bahwa dari semua Kecamatan yang ada di Kabupaten Minahasa Selatan, Kecamatan Maesaan sudah mampu swasembada pangan namun belum mampu memberikan kehidupan yang layak bagi penduduknya. Sedangkan Kecamatan lainya belum mampu untuk swasembada pangan dan tanaman pangan belum memberikan kontribusi yang besar bagi kehidupan penduduk Kabupaten Minahasa Selatan. Karena itu di perlukan usaha untuk lebih meningkatkan tingkat daya dukung lahan tanaman pangan di Kabupaten Minahasa Selatan, seperti peningkatan luas panen melalui tambahan luas tanam atau melalui usaha intensifikasi. 
Tabel 11. Daya Dukung Lahan Pertanian Tanaman Kedelai Tahun 2010 - 2014

\begin{tabular}{|c|c|c|c|c|c|c|}
\hline No & Kecamatan & 2010 & 2011 & 2012 & 2013 & 2014 \\
\hline 1 & Modoinding & 0,00000 & 0,00000 & 0,00000 & 0,00000 & 0,00000 \\
\hline 2 & Tompasobaru & 0,01889 & 0,01364 & 0,00000 & 0,01328 & 0,00000 \\
\hline 3 & Maesaan & 0,05421 & 0,06605 & 0,02236 & 0,04160 & 0,02341 \\
\hline 4 & Ranoyapo & 0,00000 & 0,00000 & 0,00000 & 0,00000 & 0,00000 \\
\hline 5 & Motoling & 0,00000 & 0,00000 & 0,00000 & 0,00724 & 0,01400 \\
\hline 6 & Kumelembuai & 0,00000 & 0,00000 & 0,00000 & 0,00000 & 0,00000 \\
\hline 7 & Motoling barat & 0,00000 & 0,00000 & 0,00000 & 0,00000 & 0,00000 \\
\hline 8 & Motoling Timur & 0,00000 & 0,00000 & 0,00000 & 0,00000 & 0,00000 \\
\hline 9 & Sinonsayang & 0,00391 & 0,00000 & 0,00000 & 0,00000 & 0,00000 \\
\hline 10 & Tenga & 0,00000 & 0,00000 & 0,00000 & 0,00562 & 0,00000 \\
\hline 11 & Amurang & 0,00000 & 0,00000 & 0,00000 & 0,00000 & 0,00000 \\
\hline 12 & Amurang Barat & 0,02100 & 0,01007 & 0,03218 & 0,00344 & 0,00341 \\
\hline 13 & Amurang Timur & 0,00768 & 0,00283 & 0,00000 & 0,00546 & 0,00538 \\
\hline 14 & Tareran & 0,00000 & 0,00000 & 0,00000 & 0,00000 & 0,00000 \\
\hline 15 & Sulta & 0,00000 & 0,00000 & 0,00000 & 0,00000 & 0,00338 \\
\hline 16 & Tumpaan & 0,00000 & 0,00000 & 0,00000 & 0,00000 & 0,00000 \\
\hline 17 & Tatapaan & 0,01092 & 0,03112 & 0,01731 & 0,00850 & 0,00270 \\
\hline
\end{tabular}

Sumber : Diolah dari lampiran 1

Tabel 12. Rata - Rata Tingkat Daya Dukung Lahan Pertanian di Kabupaten Minahasa Selatan Tahun 2010 - 2014

\begin{tabular}{|c|c|c|c|c|c|c|c|}
\hline No & Kecamatan & 2010 & 2011 & 2012 & 2013 & 2014 & Rata - Rata \\
\hline 1 & Modoinding & 0,09618 & 0,04647 & 0,08619 & 0,05518 & 0,09737 & 0,076 \\
\hline 2 & Tompasobaru & 0,86970 & 0,88597 & 0,88157 & 0,81504 & 0,85606 & 0,861 \\
\hline 3 & Maesaan & 1,11868 & 1,10198 & 0,99237 & 1,22676 & 1,12711 & 1,113 \\
\hline 4 & Ranoyapo & 0,79753 & 0,78022 & 0,85926 & 0,82211 & 0,76584 & 0,804 \\
\hline 5 & Motoling & 0,29033 & 0,20511 & 0,37733 & 0,33517 & 0,31379 & 0,304 \\
\hline 6 & Kumelembuai & 0,16253 & 0,28127 & 0,19120 & 0,15543 & 0,14996 & 0,188 \\
\hline 7 & Motoling barat & 0,20256 & 0,24073 & 0,21356 & 0,19815 & 0,20646 & 0,212 \\
\hline 8 & $\begin{array}{l}\text { Motoling } \\
\text { Timur }\end{array}$ & 0,11887 & 0,15241 & 0,12509 & 0,07421 & 0,11459 & 0,117 \\
\hline 9 & Sinonsayang & 0,46243 & 0,38209 & 0,44154 & 0,39162 & 0,45772 & 0,427 \\
\hline 10 & Tenga & 0,54731 & 0,61799 & 0,58118 & 0,54738 & 0,53269 & 0,565 \\
\hline 11 & Amurang & 0,08196 & 0,10499 & 0,07034 & 0,06560 & 0,07769 & 0,080 \\
\hline 12 & Amurang Barat & 0,64530 & 0,38712 & 0,59151 & 0,70452 & 0,63568 & 0,592 \\
\hline 13 & $\begin{array}{l}\text { Amurang } \\
\text { Timur }\end{array}$ & 0,32021 & 0,29575 & 0,30269 & 0,32052 & 0,29921 & 0,307 \\
\hline 14 & Tareran & 0,34549 & 0,26863 & 0,29666 & 0,32305 & 0,34214 & 0,315 \\
\hline 15 & Sulta & 0,27878 & 0,20854 & 0,27368 & 0,27351 & 0,27324 & 0,261 \\
\hline 16 & Tumpaan & 0,21151 & 0,36206 & 0,29072 & 0,27007 & 0,17873 & 0,262 \\
\hline 17 & Tatapaan & 0,41944 & 0,69912 & 0,61472 & 0,60053 & 0,37146 & 0,541 \\
\hline \multicolumn{7}{|c|}{ Rata - Rata } & 0,414 \\
\hline
\end{tabular}

Sumber : Diolah dari data lampiran 1 


\section{Pertanian \\ Klasifikasi Tingkat Daya Dukung Lahan}

Wilayah yang mampu swasembadah pangan adalah wilayah yang dapat memenuhi kebutuhan fisik minimu (KFM) penduduk sebesar $2.600 \mathrm{ka}-$ lori/orang/tahun. Sedangkan untuk wilayah yang mampu mermberikan kehidupan yang layak bagi penduduk yang tergantung pada tanaman pangan adalah wilayah yang dapat memenuhi kebutuhan hidup dalam taraf yang layak yaitu setara dengan $650 \mathrm{~kg}$ beras/orang/tahun atau 2,466 kali KFM (Moniaga, 2011). Berdasarkan nilai-nilai tersebut maka klasifikasi yang diterapkan adalah :
1. Kelas I
$\sigma>2,466$
: Wilayah yang mampu swasembada pangan dan mampu memberikan kehidupan yang layak bagi penduduknya.
2. Kelas II $\quad 1 \leq \sigma \leq 2,466$
3. Kelas III $\quad \sigma<1$
: Wilayah yang mampu swasembada pangan tetapi belum mampu memberikan kehidupan yang layak bagi penduduknya : Wilayah yang belum mampu swasembada pangan

Tabel 13. Klasifikasi Rata - Rata Tingkat Daya Dukung Lahan Pertanian di Kabupaten Minahasa Selatan Tahun 2010 - 2014

\begin{tabular}{clcc}
\hline Kelas & Daya Dukung Lahan Pertanian & Jumlah & Lokasi \\
\hline I & $\sigma>2,466$ & - & - \\
II & $1 \leq \sigma \leq 2,466$ & 1 & $\begin{array}{c}\text { Maesaan } \\
\end{array}$ \\
& $\sigma<1$ & 16 & $\begin{array}{c}\text { Tompasobaru, Ranoyapo, Modoinding, } \\
\text { Motoling, Tenga, Sinonsayang, } \\
\end{array}$ \\
& & & $\begin{array}{c}\text { Amurang, Tumpaan, Sulta, Tatapaan, } \\
\text { Kumelembuai, Motoling Barat, Motoling } \\
\end{array}$ \\
& & & Timur, Amurang Barat, Amurang Timur, \\
& & & Tareran \\
\hline
\end{tabular}

Dari hasil perhitungan pada Tabel 6 rata rata perkembangan daya dukung lahan pertanian pada tingkat Kecamatan di Kabupaten Minahasa Selatan tahun 2010 - 2014, maka klasifikasi daya dukung lahan pertanian pada tiap - tiap kelas dapat di lihat pada Tabel 13.

\section{Diversifikasi Konsumsi}

Dalam peraturan Menteri Pertanian No 43 Tahun 2009 yaitu upaya untuk penganekaragaman konsumsi pangan yang tidak hanya berfokus pada satu tanaman pangan tetapi bisa untuk tanaman lainya dan sumber makanan lainya. Jika ada diversifikasi konsumsi yang memenuhi kebutuhan kalori minimum maka akan mempengarui daya dukung padi. Jika 60 $\%$ kebutuhan kalori dipenuhi padi sedangkan sisanya di penuhi komodoti lain maka daya dukung lahan tanaman padi dapat dilihat pada Tabel 14. Pada Tabel
14 daya dukung tanaman padi dan pada tabel 6 daya dukung tanaman padi dilihat sangat mempengarui angka daya dukung. Setelah diversifikasi pada Tabel 14 tahun 2014 Kecamatan Tompasobaru 1,536 , Maesaan 1,704, dan Ranoyapo 1,622 Sedangkan sebelum diversifikasi pada tabel 6 tahun 2014 Kecamatan Tompasobaru 2,561, Maesaan 2,840 dan Ranoyapo 2,704. Dari hasil tersebut bahwa diversifikasi pangan sangat mempegarui daya dukung padi sehingga swasembada pangan akan terpenuhi dengan adanya penganekaragaman konsumsi yang tidak hanya beras tetapi makanan lainya.

Dari hasil Survei BPS Pada tahun 2015 konsumsi beras per kapita per tahun menjadi $113 \mathrm{~kg}$, Dengan nilai rata - rata 1,184 Kabupaten Minahasa Selatan sudah mampu swasembada pangan namun belum memberikan kehidupan yang layak bagi penduduknya (Lampiran 4). 
Tabel 14. Daya Dukung Lahan Tanaman Padi Tahun 2010-2014 Diversifikasi $60 \%$

\begin{tabular}{cllllllr}
\hline No & Kecamatan & 2010 & 2011 & 2012 & 2013 & 2014 & Rata Rata \\
\hline 1 & Modoinding & 0,0000 & 0,0000 & 0,0000 & 0,0000 & 0,0000 & 0,0000 \\
2 & Tompasobaru & 1,5611 & 1,4260 & 1,6013 & 1,4774 & 1,5368 & 1,5205 \\
3 & Maesaan & 1,6911 & 1,9660 & 1,7450 & 1,8068 & 1,7042 & 1,7826 \\
4 & Ranoyapo & 1,7294 & 1,7416 & 1,8702 & 1,8184 & 1,6226 & 1,7564 \\
5 & Motoling & 0,1867 & 0,2007 & 0,2631 & 0,2539 & 0,1609 & 0,2131 \\
6 & Kumelembuai & 0,0872 & 0,0411 & 0,0509 & 0,0727 & 0,0590 & 0,0622 \\
7 & Motoling barat & 0,0856 & 0,1432 & 0,1941 & 0,1898 & 0,0847 & 0,1395 \\
8 & Motoling Timur & 0,0376 & 0,0367 & 0,0421 & 0,0426 & 0,0341 & 0,0386 \\
9 & Sinonsayang & 0,4548 & 0,3753 & 0,3965 & 0,3339 & 0,4245 & 0,3970 \\
10 & Tenga & 0,7922 & 0,9176 & 0,8512 & 0,8095 & 0,7435 & 0,8228 \\
11 & Amurang & 0,0000 & 0,0056 & 0,0141 & 0,0239 & 0,0000 & 0,0087 \\
12 & Amurang Barat & 0,0482 & 0,0485 & 0,0933 & 0,1274 & 0,0412 & 0,0717 \\
13 & Amurang Timur & 0,2390 & 0,1792 & 0,2766 & 0,3560 & 0,1903 & 0,2482 \\
14 & Tareran & 0,3190 & 0,2034 & 0,3197 & 0,4558 & 0,3066 & 0,3209 \\
15 & Sulta & 0,0539 & 0,0347 & 0,0583 & 0,0529 & 0,0571 & 0,0514 \\
16 & Tumpaan & 0,6743 & 0,4762 & 0,5575 & 0,5198 & 0,5779 & 0,5611 \\
17 & Tatapaan & 1,2626 & 1,1301 & 0,9624 & 0,7807 & 1,1170 & 1,0505 \\
\hline
\end{tabular}

Sumber : Di olah dari lampiran 3

\section{Jumlah Penduduk Optimal ( JPO)}

Daya dukung lahan yang seimbang ditentukan apabila luas lahan pertanian yang ada pada suatu wilayah dapat memenuhi kebutuhan fisik minimum penduduknya. Keseimbangan daya dukung lahan pertanian pada penelitian ini diwujudkan dalam suatu keadaan dimana jumlah penduduk optimal yang mampu di dukung oleh hasil tanaman pangan dari lahan pertanian yang ada.

$$
\mathrm{JPO}=\sigma \mathrm{x} \text { penduduk }
$$

Jumlah penduduk optimal dalam penelitian ini adalah banyaknya jiwa yang dapat didukung oleh lahan pertanian yang ada. Apabila jumlah penduduk optimal dan diperoleh lebih kecil dari jumlah penduduk yang terdata maka diperlukan penambahan luas panen yang dapat mendukung kehidupan penduduk tersebut.
Dari hasil Tabel 15 menunjukkan bahwa hanya Kecamatan Maesaan yang dapat memenuhi semua kebutuhan penduduk yang ada karena jumlah penduduk optimal lebih besar dari jumlah penduduk yang terdata. sedangkan Kecamatan lain diperoleh lebih kecil dari jumlah penduduk yang terdata, memerlukan tambahan luas panen yang dapat mendukung penduduk tersebut.

Selain tambahan luas panen, dapat juga dilakukan dengan cara peningkatan produksi tanaman pangan, menanam tanaman pangan dibawah tanaman lain seperti tanaman kelapa, cengkeh, atau melalui usaha intensifikasi untuk mendukung penduduk tersebut. Sehingga daya dukung lahan bisa terjadi dan perlukan adanya penganekaragaman konsumsi yang tidak berfokus pada beras saja tetapi pada makanan lainya agar kecukupan pangan bisa terpenuhi dan daerah tersebut mengalami swasembada pangan. 
Tabel 15. Jumlah Penduduk Optimal ( JPO) Tahun 2014

\begin{tabular}{lccc}
\multicolumn{1}{c}{ Kecamatan } & $\begin{array}{c}\text { Jumlah } \\
\text { penduduk }\end{array}$ & Daya dukung Lahan & $\begin{array}{c}\text { Jumlah } \\
\text { penduduk opti- } \\
\text { mal }\end{array}$ \\
\hline Modoinding & 11822 & 0,09737 & 1151 \\
Tompasobaru & 11819 & 0,85606 & 10117 \\
Maesaan & 9832 & 1,12711 & 11081 \\
Ranoyapo & 12089 & 0,76584 & 9258 \\
Motoling & 7225 & 0,31379 & 2267 \\
Kumelembuai & 6553 & 0,14996 & 982 \\
Motoling barat & 7706 & 0,20646 & 1590 \\
Motoling Timur & 8995 & 0,11459 & 1030 \\
Sinonsayang & 15283 & 0,45772 & 6995 \\
Tenga & 17444 & 0,53269 & 9292 \\
Amurang & 17112 & 0,07769 & 1329 \\
Amurang Barat & 15345 & 0,63568 & 9754 \\
Amurang Timur & 14270 & 0,29921 & 4269 \\
Tareran & 12261 & 0,34214 & 4194 \\
Sulta & 7226 & 0,27324 & 1974 \\
Tumpaan & 16061 & 0,17873 & 2870 \\
Tatapaan & 9029 & 0,37146 & 3353 \\
\hline Sumbr : Data & & &
\end{tabular}

Sumber : Data diolah

\section{KESIMPULAN DAN SARAN}

\section{Kesimpulan}

Rata - rata keseluruhan daya dukung lahan pertanian tanaman pangan di Kabupaten Minahasa Selatan dari Tahun 2010 -
2014 adalah 0,414. Hal ini berarti lahan pertanian tanaman pangan yang ada di Kabupaten Minahasa Selatan belum mampu untuk melakukan swasembada pangan dan belum mampu memberikan kecukupan pangan. 


\section{Saran}

Sebagai saran berdasarkan penelitian ini, adalah:

a. Perlu dilakukan upaya - upaya untuk meningkatkan daya dukung lahan pertanian dengan cara penanaman lahan kosong, menambah luas panen tanaman pangan dan menekan laju pertumbuhan penduduk.

b. Diversifikasi pangan perlu dilakukan agar supaya kecukupan pangan bisa terjadi.

\section{DAFTAR PUSTAKA}

Arie Fitriani 2005. Analisis Daya Dukung Lahan Pertanian dan Tekanan Penduduk studi Kasus Kabupaten Propinsi Jawa Timur.(Skripsi) Universitas Sebelas Maret .Surakarta .http://eprints.uns.ac.id /7505/1/68892206200906221. pdf Di akses pada tanggal 26 oktober 2015 .

Arifin, B. 2007. Diagnosis Ekonomi Politik Pangan dan Pertanian. PT.Raja Grafindo Persada. Jakarta.

BPS, Minsel, 2014. Kabupaten Minahasa Selatan dalam Angka. Badan Pusat Statistik, Manado.

Baja Sumbangan 2012. Perencanaan Tata Guna Lahan dalam pengembangan wilayah dan pendekatan spasial dan aplikasinya. Andi. Yogyakarta.

Basri. H. Jumin, 2010. Dasar - Dasar Agronomi. Rajawali Press. Jakarta .
Idewa Darma Putra, 2015. Analisis Daya Dukung Lahan Berdasarkan Total Nilai Produksi Pertanian di Kabupaten Gianyar. (Tesis). Universitas Udayana. Denpasar. http:// www .pps. unud ac.id /thesis/ pdf thesis/unud-12731027751435-tesis.pdf Di akses pada tanggal 20 April 2015.

Ida Bagoes Mantra. 2003. Demografi Umum. Pustaka Pelajar. Yogyakarta.

Karwan A. Salikin, 2003. Sistem Pertanian Berkelanjutan. Kanisius. Yogyakarta.

Lagarense Vinny, 2015. Faktor - Faktor Yang Mempengarui Alih Fungsi Lahan Pertanian Di Kabupaten Minahasa Selatan. (Skripsi) Jurusan Sosial Ekonomi Fakultas Pertanian. Universitas Sam Ratulangi. Manado.

Moerhar Daniel, 2004. Pengantar Ekonomi Pertanian. PT Bumi Aksara. Jakarta.

Moniaga V. R. B., 2011. Analisis Daya Dukung Lahan Pertanian. (Jurnal) ASE Volume 7 Nomor 2. Jurusan Sosial Ekonomi Fakultas Pertanian Universitas Sam Ratulangi. Manado.

Purwono dan Heni, 2007. Budidaya 8 Jenis Tanaman Pangan Unggun 1. Penebar Swadaya. Jakarta.

Riyadi dan Bratakusumah, Deddy. 2004. Perencanaan Pembangunan Daerah: Strategi Menggali Potensi dalam Mewujudkan Otonomi Daerah. Gramedia Pustaka Utama. Jakarta. 
Sitanala Arsyad, 2008. Penyelamatan Tanah, Air dan Lingkungan. Crestpent Press dan Yayasan Obor Indonesia. Jakarta.

Taringan, Robinson. 2004. Perencanaan Pembangunan Wilayah. PT. Bumi Aksara. Jakarta.
Tulenan Yoan F. A, 2014. Perkembangan Jumlah Penduduk dan Luas Lahan Pertanian Di Kabupaten Minahasa Selatan. (Skripsi) Jurusan Sosial Ekonomi Fakultas Pertanian Universitas Sam Ratulangi. Manado.

Weol Frelyne, 2007. Daya Dukung Lahan Pertanian Tanaman Pangan Di Kabupaten Minahasa Utara. (Skripsi ). Jurusan Sosial Ekonomi Fakultas Pertanian Universitas Sam Ratulangi. Manado. 